\title{
Low dose interferon alfa-2b for chronic hepatitis B in Asian countries
}

\author{
E Mauracher
}

Essex Asia Ltd, Hong Kong E Mauracher Correspondence to: Dr E Mauracher, Essex Asia Ltd, 1201 Citicorp Center, 18 Whitfield Road, Causeway Bay, Hong Kong.

\begin{abstract}
In a study of low dose interferon alfa-2b in 587 patients expected to show a good response to treatment, $76-87 \%$ patients in different countries had alanine aminotransferase activities returned to normal after four months' treatment, 49-72\% were negative for hepatitis B virus (HBV)DNA, $51-66 \%$ were negative for hepatitis $B$ e antigen (HBeAg), and 44-62\% were anti-HBe positive. These effects were maintained after nine to 12 months' follow up. Side effects were mild, but led to discontinuation of treatment in 12 patients.

(Gut 1993; supplement: S99-S100)
\end{abstract}

\begin{tabular}{|c|c|c|c|c|c|}
\hline \multirow[t]{2}{*}{$\mid$} & A & \multirow[t]{2}{*}{ B } & \multicolumn{3}{|c|}{ C } \\
\hline & & & Daily & \multicolumn{2}{|c|}{ INTRON A: TIW } \\
\hline 02 & 46 & \multicolumn{2}{|c|}{$\begin{array}{c}8 \\
(10)\end{array}$} & \multicolumn{2}{|c|}{ Weeks } \\
\hline A & \multicolumn{3}{|c|}{$\begin{array}{l}\text { Corticosteroid } \\
\text { e.g. prednisolone } \\
\text { ( } 6 \text { weeks) }\end{array}$} & $\begin{array}{l}\text { Withdrawal } \\
45 \mathrm{mg} \text { daily } \\
30 \mathrm{mg} \text { daily } \\
15 \mathrm{mg} \text { daily }\end{array}$ & \\
\hline B & \multicolumn{3}{|c|}{$\begin{array}{l}\text { Rest period } \\
\text { (2-4 weeks) }\end{array}$} & \multicolumn{2}{|c|}{$\begin{array}{l}\text { No drugs for } 2-4 \text { weeks } \\
\text { depending on patient's reaction }\end{array}$} \\
\hline C & \multicolumn{3}{|c|}{$\begin{array}{l}\text { Low dosage } \\
\text { INTRON ( } 4 \text { months) } \\
3 \text { MU daily sc, for } 2 \\
\text { weeks followed by } 3 \mathrm{MU} \\
\text { TIW sc, for } 14 \text { weeks }\end{array}$} & \multicolumn{2}{|c|}{$\begin{array}{l}\text { For patients with a less than 7-year history } \\
\text { of } \mathrm{HBV} \text { infection and those who are } \\
\text { considered favourable responders }\end{array}$} \\
\hline
\end{tabular}

Figure Treatment schedule. TIW $\mathrm{W}=$ three times weekly.

TABLE I Patient characteristics $(n=587)$

\begin{tabular}{lcccccc}
\hline & Indonesia & Korea & China & Thailand & Others & Total \\
\hline Numbers of centres & 3 & 4 & 4 & 3 & 12 & 26 \\
Number of patients enrolled & 81 & 119 & 111 & 41 & 235 & 587 \\
Protocol violations & 2 & 5 & 3 & 0 & 31 & 41 \\
Withdrawals (not treatment related) & 4 & 4 & 8 & 2 & 39 & $57(9 \cdot 7 \%)$ \\
Discontinued (side effects) & 0 & 3 & 1 & 0 & 8 & $12(2 \cdot 0 \%)$ \\
Higher dosage required & 0 & 3 & 2 & 1 & 31 & $37(6 \cdot 3 \%)$ \\
Evaluable patients & 75 & 104 & 97 & 38 & 126 & 440 \\
Sex (Male/Female) & $53 / 22$ & $76 / 28$ & $81 / 16$ & $28 / 10$ & $104 / 22$ & $342 / 98$ \\
Mean age (y) & $27 \cdot 3$ & $29 \cdot 4$ & $31 \cdot 2$ & $29 \cdot 2$ & $34 \cdot 3$ & $29 \cdot 2$ \\
\hline
\end{tabular}

*Others are centres in Hong Kong, Japan, Malaysia, and Taiwan.
The aim of this study was to evaluate the efficacy and degree of tolerance to low dose interferon alfa-2b (INTRON A) in carefully selected Asian patients with chronic hepatitis B virus (HBV) infection. The rationale for the protocol was based on previous publications describing the type of patients who should show a good response to interferon alfa- $2 b$ treatment. ${ }^{1-8}$

\section{Patients and methods}

Investigators were asked to include only those patients with a potentially favourable response to interferon alfa- $2 \mathrm{~b}$. To be enrolled in the study, therefore, patients had to have been infected later in life, and be under 50 years of age, negative for antibodies to HIV (antiHIV), and without delta or hepatitis C virus superinfection. They were also required to have serum alanine aminotransferase (ALT) activities at least twice the upper limit of normal, with low viral replication - that is, low HBV-DNA titres, and a medium to high histology activity index for chronic hepatitis B.

Corticosteroids were given for six weeks in a reducing dose, followed by a two to four week rest period, and then four months of low dose interferon alfa- $2 \mathrm{~b}$, according to the schedule shown in the Figure.

\section{Results}

Five hundred and eighty seven patients were enrolled from eight different Asian countries and a total of 26 centres. Of these, 440 patients (342 males and 98 females, mean age $29 \cdot 2$ years) were suitable for evaluation treatment of efficacy and tolerance. Of the 147 patients who were not suitable, 57 withdrew because of effects not related to treatment, 41 were not suitable because of protocol violations, 37 required higher dosages, and 12 discontinued treatment because of side effects. Patient characteristics for the 587 enrolled are shown in Table I.

After four months of treatment with interferon alfa- $2 b, 76-87 \%$ of patients in different countries had regained normal serum ALT activities, $49-72 \%$ were negative for $\mathrm{HBV}$ DNA, 51-66\% were negative for hepatitis B e 
TABLE II Effects of INTRON A (3 million units (MU)) after four months of treatment

\begin{tabular}{|c|c|c|c|c|c|c|}
\hline & Indonesia & Korea & China & Thailand & Others* & Total \\
\hline $\begin{array}{l}\text { Number of patients } \\
\text { Male/female } \\
\text { ALT (\%) }\end{array}$ & $\begin{array}{l}75 \\
53 / 22\end{array}$ & $\begin{array}{l}104 \\
76 / 28\end{array}$ & $\begin{array}{l}97 \\
81 / 16\end{array}$ & $\begin{array}{l}38 \\
28 / 10\end{array}$ & $\begin{array}{l}126 \\
104 / 22\end{array}$ & $\begin{array}{l}440 \\
342 / 98\end{array}$ \\
\hline $\begin{array}{l}\text { Returned to normal } \\
\text { No change } \\
\text { HBV-DNA }(\%)\end{array}$ & $\begin{array}{l}87 \\
13\end{array}$ & $\begin{array}{l}82 \\
18\end{array}$ & $\begin{array}{l}87 \\
13\end{array}$ & $\begin{array}{l}76 \\
24\end{array}$ & $\begin{array}{l}85 \\
15\end{array}$ & $\begin{array}{l}76-87 \% \\
13-24 \%\end{array}$ \\
\hline $\begin{array}{l}\text { No change } \\
\text { Decreased } \\
\text { Negative } \\
\mathrm{HBeAg}(\%)\end{array}$ & $\begin{array}{l}13 \\
15 \\
72\end{array}$ & $\begin{array}{l}27 \\
16 \\
57\end{array}$ & $\begin{array}{l}24 \\
18 \\
58\end{array}$ & $\begin{array}{l}28 \\
12 \\
60\end{array}$ & $\begin{array}{l}21 \\
30 \\
49\end{array}$ & $\begin{array}{l}13-28 \% \\
12-30 \% \\
49-72 \%\end{array}$ \\
\hline $\begin{array}{l}\text { No change } \\
\text { Decreased } \\
\text { Negative }\end{array}$ & $\begin{array}{r}8 \\
26 \\
66\end{array}$ & $\begin{array}{l}20 \\
29 \\
51\end{array}$ & $\begin{array}{l}16 \\
32 \\
52\end{array}$ & $\begin{array}{l}29 \\
16 \\
55\end{array}$ & $\begin{array}{l}23 \\
26 \\
51\end{array}$ & $\begin{array}{r}8-29 \% \\
16-32 \% \\
51-66 \%\end{array}$ \\
\hline $\begin{array}{l}\text { Anti-HBe (\%) } \\
\text { Negative } \\
\text { Positive } \\
\text { HBsAg (\%) }\end{array}$ & $\begin{array}{l}38 \\
62\end{array}$ & $\begin{array}{l}56 \\
44\end{array}$ & $\begin{array}{l}55 \\
45\end{array}$ & $\begin{array}{l}48 \\
52\end{array}$ & $\begin{array}{l}52 \\
48\end{array}$ & $\begin{array}{l}38-56 \% \\
44-62 \%\end{array}$ \\
\hline Negative & 5 & 4 & 2 & 5 & 3 & $2-5 \%$ \\
\hline
\end{tabular}

^Others: Hong Kong, Japan, Malayasia, and Taiwan.

TABLE III Effects of INTRON A (3 million units) after nine to 12 months of treatment

\begin{tabular}{|c|c|c|c|c|c|c|}
\hline & Indonesia & Korea & China & Thailand & Others* & Total \\
\hline $\begin{array}{l}\text { Number of patients }(\%) \\
\text { Male/female } \\
\text { ALT }(\%)\end{array}$ & $\begin{array}{l}22 \\
11 / 11\end{array}$ & $\begin{array}{l}64 \\
54 / 10\end{array}$ & $\begin{array}{l}42 \\
36 / 6\end{array}$ & $\begin{array}{l}20 \\
12 / 8\end{array}$ & $\begin{array}{l}91 \\
75 / 16\end{array}$ & $\begin{array}{l}239(54 \%) \\
188 / 51\end{array}$ \\
\hline $\begin{array}{l}\text { Returned to normal } \\
\text { No change }\end{array}$ & $\begin{array}{l}77 \\
23\end{array}$ & $\begin{array}{l}75 \\
25\end{array}$ & $\begin{array}{l}77 \\
23\end{array}$ & $\begin{array}{l}90 \\
10\end{array}$ & $\begin{array}{l}84 \\
16\end{array}$ & $\begin{array}{l}75-90 \% \\
10-25 \%\end{array}$ \\
\hline $\begin{array}{l}\text { HBV-DNA (\%) } \\
\text { Increased } \\
\text { Decreased } \\
\text { Negative } \\
\mathrm{HBeAg}(\%)\end{array}$ & $\begin{array}{l}\text { Not } \\
\text { yet } \\
\text { available }\end{array}$ & $\begin{array}{l}28 \\
18 \\
54\end{array}$ & $\begin{array}{l}30 \\
18 \\
52\end{array}$ & $\begin{array}{l}15 \\
25 \\
60\end{array}$ & $\begin{array}{l}16 \\
26 \\
58\end{array}$ & $\begin{array}{l}15-30 \% \\
18-26 \% \\
52-60 \%\end{array}$ \\
\hline $\begin{array}{l}\text { Increased } \\
\text { Decreased } \\
\text { Negative }\end{array}$ & $\begin{array}{r}0 \\
32 \\
68\end{array}$ & $\begin{array}{l}17 \\
25 \\
58\end{array}$ & $\begin{array}{l}24 \\
20 \\
56\end{array}$ & $\begin{array}{l}15 \\
31 \\
54\end{array}$ & $\begin{array}{l}23 \\
17 \\
60\end{array}$ & $\begin{array}{r}0-24 \% \\
17-32 \% \\
54-68 \%\end{array}$ \\
\hline $\begin{array}{l}\text { Anti-HBe (\%) } \\
\text { Negative } \\
\text { Positive } \\
\text { HBsAg (\%) }\end{array}$ & $\begin{array}{l}30 \\
70\end{array}$ & $\begin{array}{l}52 \\
48\end{array}$ & $\begin{array}{l}53 \\
47\end{array}$ & $\begin{array}{l}48 \\
52\end{array}$ & $\begin{array}{l}48 \\
52\end{array}$ & $\begin{array}{l}30-53 \% \\
47-70 \%\end{array}$ \\
\hline $\begin{array}{l}\text { Negative } \\
\text { Positive } \\
\text { Histology (\%) }\end{array}$ & $\begin{array}{l}18 \\
82\end{array}$ & $\begin{array}{r}8 \\
92\end{array}$ & $\begin{array}{r}7 \\
93\end{array}$ & $\begin{array}{l}10 \\
90\end{array}$ & $\begin{array}{r}9 \\
91\end{array}$ & $\begin{array}{r}7-18 \% \\
82-93 \%\end{array}$ \\
\hline $\begin{array}{l}\text { No repeat } \\
\text { Improved } \\
\text { No change }\end{array}$ & $\begin{array}{l}50 \\
36 \\
14\end{array}$ & $\begin{array}{r}57 \\
38 \\
5\end{array}$ & $\begin{array}{l}60 \\
30 \\
10\end{array}$ & $\begin{array}{r}40 \\
60 \\
0\end{array}$ & $\begin{array}{l}40 \\
24 \\
36\end{array}$ & $\begin{array}{r}40-60 \% \\
24-60 \% \\
0-36 \%\end{array}$ \\
\hline
\end{tabular}

^Others: Hong Kong, Japan, Malayasia, and Taiwan.

TABLE IV Side effects during treatment

\begin{tabular}{lrll}
\hline Minor side effects (\% patients) & & \multicolumn{2}{l}{$\begin{array}{l}\text { Side effects which caused the treatment } \\
\text { to be discontinued ( } n=12)\end{array}$} \\
\hline Flu like symptoms & & Hair loss & 4 patients \\
$\quad$ (fatigue, fever, headache, myalgia) & & Severe flu like symptoms & 3 patients \\
$\quad$ During first 2 weeks & 84 & Loss of weight and appetite & 3 patients \\
$\quad$ During later treatment & 12 & Skin rash & 2 patients \\
Loss of appetite (temporary) & 6 & & \\
Nausea (temporary) & 2 & & \\
Hair loss (after 2-3 months) & 4 & & \\
Depression, irritability, dizziness & $<1$ & & \\
\hline
\end{tabular}

antigen $(\mathrm{HBeAg})$ and $44-62 \%$ were anti-HBe antibody positive (Table II). These effects were consistent between the populations of different Asian countries and were maintained after nine to 12 months' follow up (Table III). Three to six months after treatment, the rate of hepatitis B surface antigen (HBsAg) loss had increased from $2-5 \%$ to $7-18 \%$ in different countries, and $24-60 \%$ of patients also showed improvements when the liver was examined histologically.

Side effects were generally mild but led to discontinuation of treatment in 12 patients (not included in the efficacy results) (Table IV).

\section{Conclusions}

Although only those patients who were considered to be good candidates for interferon alfa-2b treatment were included in this study, the results indicate that a considerable number of Asian patients do respond to low dose interferon alfa- $2 b$ treatment.

1 Hoofnagle JH, Peters M, Mullen KD, et al. Randomized, controlled trial of recombinant human alpha-interferon in patients with chronic hepatitis B. Gastroenterology 1988; 95: 1318-25.

2 Perrillo RP, Regenstein FG, Peters MG, et al. Prednisone withdrawal followed by recombinant alpha interferon in the treatment of chronic type B hepatitis. A randomized, controlled trial. Ann Intern Med 1988; 109: 95-100.

3 Dooley JS, Davis GL, Peters M, et al. Pilot study of recombinant human alpha-interferon for chronic type B hepatitis. Gastroenterology 1986; 90: 150-7.

4 Brook MG, McDonald JA, Karayiannis P, et al. Randomised controlled trial of interferon alfa $2 \mathrm{~A}$ (rbe) (Roferon-A) for the treatment of chronic hepatitis B virus (HBV) infection: factors that influence response. Gut 1989; 30 1116-22.

5 Brook MG, Marayiannis P, Thomas HC. Which patients with chronic hepatitis $B$ virus infection will respond to alpha-interferon therapy? A statistical analysis of predictive factors. Hepatology 1989; 10: 761-3.

6 Perrillo RP. Factors influencing response to interferon in chronic hepatitis B: Implications for Asian and Western populations. Hepatology 1990; 12: 1433-5.

7 Sherlock S. Treatment of chronic viral hepatitis. 7 Hepatol 1988; 6: 113-5.

8 Lok ASF, Lai C-L, Wu P-C, Leung EKY. Long-term follow-up in a randomised controlled trial of recombinan $\alpha_{2}$-interferon in Chinese patients with chronic hepatitis B infection. Lancet 1988; ii: 298-302. 